\title{
Kawasaki disease and influenza—new lessons from old associations
}

\author{
Aaqib Zaffar Banday ${ }^{1}$ (D) Ashwini Arul $^{1}$ (D) $\cdot$ Pandiarajan Vignesh $^{1}$ (D) $\cdot$ Mini P. Singh $^{2} \cdot$ Kapil Goyal $^{2} \cdot$ Surjit Singh $^{1}$ (D)
}

Received: 1 November 2020 /Revised: 27 November 2020 / Accepted: 1 December 2020 / Published online: 2 January 2021

(C) International League of Associations for Rheumatology (ILAR) 2021

\begin{abstract}
Kawasaki disease (KD), an enigmatic medium vessel vasculitis, presents as an acute febrile illness predominantly affecting young children. KD appears to be a hyper-inflammatory response elicited by environmental or infectious agents (including respiratory viruses) in genetically predisposed individuals. Numerous reports from the current era of severe acute respiratory syndrome coronavirus 2 (SARS-CoV-2) pandemic have described the occurrence of KD/KD-like illness in close temporal proximity to SARS-CoV-2 infection or exposure. Notably, $\mathrm{KD}$ has been reported in association with $\mathrm{H}_{1} \mathrm{~N}_{1}$-pdm09 virus that caused the previous pandemic a decade ago. Non- $\mathrm{H}_{1} \mathrm{~N}_{1}$ influenza infections as well as influenza vaccination have also been reported to trigger KD. Herein, we report a case of $\mathrm{H}_{1} \mathrm{~N}_{1}$-pdm09 influenza who developed KD. We review the published literature on influenza infection or vaccination triggering $\mathrm{KD}$. This may help in a better understanding of the $\mathrm{KD} / \mathrm{KD}$-like illness associated with SARS-CoV-2. Besides, we also evaluate the safety of aspirin in influenza-triggered KD as aspirin administration in children with influenza is associated with the risk of development of Reye syndrome.
\end{abstract}

Keywords Aspirin · Coronavirus · COVID-19 $\cdot$ Influenza $\cdot$ Kawasaki disease $\cdot$ SARS-CoV-2 $\cdot$ Vaccine

\begin{tabular}{|c|c|c|}
\hline \multirow{2}{*}{\multicolumn{2}{|c|}{ Abbreviations }} & \\
\hline & & \\
\hline \multirow{2}{*}{\multicolumn{2}{|c|}{$\begin{array}{l}\text { CAAs } \\
\text { CPAP }\end{array}$}} & Coronary artery abnormalities \\
\hline & & Continuous positive airway pressure \\
\hline \multicolumn{2}{|c|}{ CRP } & C-reactive protein \\
\hline \multicolumn{2}{|c|}{ ESR } & Erythrocyte sedimentation rate \\
\hline \multicolumn{2}{|c|}{$\mathrm{FiO}_{2}$} & Fraction of inspired oxygen \\
\hline \multicolumn{3}{|c|}{$\begin{array}{l}\triangle \text { Pandiarajan Vignesh } \\
\text { vigimmc@gmail.com }\end{array}$} \\
\hline \multicolumn{3}{|c|}{$\begin{array}{l}\text { Aaqib Zaffar Banday } \\
\text { maaqibzb@gmail.com }\end{array}$} \\
\hline \multicolumn{3}{|c|}{$\begin{array}{l}\text { Ashwini Arul } \\
\text { ashwini.am3010@gmail.com }\end{array}$} \\
\hline \multicolumn{3}{|c|}{$\begin{array}{l}\text { Mini P. Singh } \\
\text { minipsingh@gmail.com }\end{array}$} \\
\hline \multicolumn{3}{|c|}{ Kapil Goyal } \\
\hline \multicolumn{3}{|c|}{$\begin{array}{l}\text { Surjit Singh } \\
\text { surjitsinghpgi@ rediffmail.com }\end{array}$} \\
\hline 1 & $\begin{array}{l}\text { Allergy Imm } \\
\text { Graduate Inst } \\
\text { Chandigarh } 1\end{array}$ & $\begin{array}{l}\text { nology Unit, Advanced Pediatrics Centre (APC), Post } \\
\text { tute of Medical Education and Research (PGIMER), } \\
60012 \text {, India }\end{array}$ \\
\hline 2 & Department 0 & f Virology, PGIMER, Chandigarh, India \\
\hline
\end{tabular}

\begin{tabular}{|c|c|}
\hline $\mathrm{H}_{1} \mathrm{~N}_{1}$-pdm09 & $\begin{array}{l}\text { Influenza } \mathrm{A}\left(\mathrm{H}_{1} \mathrm{~N}_{1}\right) \text { virus responsible } \\
\text { for } 2009 \text { pandemic }\end{array}$ \\
\hline $\mathrm{H}_{1} \mathrm{~N}_{1}-\mathrm{KD}$ & Kawasaki disease associated with \\
\hline & $\mathrm{H}_{1} \mathrm{~N}_{1}$ influenza infection \\
\hline IVIg & Intravenous immunoglobulin \\
\hline $\mathrm{KD}$ & Kawasaki disease \\
\hline KDSS & KD shock syndrome \\
\hline NT-proBNP & N-terminal pro-B-type natriuretic peptide \\
\hline PCR & Polymerase chain reaction \\
\hline RT-PCR & $\begin{array}{l}\text { Reverse-transcription polymerase } \\
\text { chain reaction }\end{array}$ \\
\hline SARS-CoV-2 & $\begin{array}{l}\text { Severe acute respiratory syndrome } \\
\text { coronavirus } 2\end{array}$ \\
\hline $\mathrm{SpO}_{2}$ & Oxygen saturation on pulse oximetry \\
\hline
\end{tabular}

\section{Introduction}

Kawasaki disease (KD) is an acute febrile vasculitic disorder of childhood predominantly affecting medium size arteries with a predilection for coronary arteries. $\mathrm{KD}$ is now the leading cause of acquired heart disease in children worldwide [1]. The illness was first reported by Dr. Tomisaku Kawasaki, a Japanese pediatrician, in 1967 when he reported a series of 50 patients [2]. Classic or 'complete' KD clinically presents with fever for at least 5 days with four of the following clinical 
manifestations: edema of hands and feet in the acute stage and/ or subacute periungual skin peeling of fingers and toes, polymorphous exanthematous rash, non-exudative bilateral bulbar conjunctival injection, orolabial changes, and cervical lymphadenopathy. 'Incomplete' KD is diagnosed when the full diagnostic criteria of $\mathrm{KD}$ are not met [3]. The most dreaded complication in $\mathrm{KD}$ is cardiac involvement leading to development of coronary artery abnormalities (CAAs). KD shock syndrome (KDSS) is a condition in which patients present with diminished left ventricular function due to myocarditis. KDSS is often accompanied by CAAs [4].

The exact etiology of KD remains unknown. It appears that $\mathrm{KD}$ is a hyper-inflammatory response in a genetically predisposed individual that is possibly triggered by several environmental factors or infectious agents including respiratory viruses [5]. In the current novel coronavirus (SARS-CoV2) pandemic, $\mathrm{KD} / \mathrm{KD}$-like illness has been strongly associated with SARS-CoV-2 infection or exposure in children [6-8]. Similar to KD, evidence suggests that KD-like illness (postSARS-CoV-2) to be a result of aberrant immune reaction rather than the direct effect of viral infection [6-8]. This finding has renewed research interest into the role played by infections, especially respiratory viruses, in triggering anomalous inflammatory responses.

Interestingly, $\mathrm{KD}$ has also been reported in association with the $\mathrm{H}_{1} \mathrm{~N}_{1}$-pdm09 virus that was responsible for the previous pandemic a decade ago [9-12]. Besides, there are reports of $\mathrm{KD}$ in association with non- $\mathrm{H}_{1} \mathrm{~N}_{1}$ influenza infections [13-21] and also influenza vaccination [22-24]. We report herein a case of $\mathrm{H}_{1} \mathrm{~N}_{1}$-pdm09 influenza who developed $\mathrm{KD}$ $\left(\mathrm{H}_{1} \mathrm{~N}_{1}-\mathrm{KD}\right)$. We also review the published literature on the subject. Additionally, we highlight the similarities and dissimilarities between $\mathrm{KD}$ triggered by influenza infection and $\mathrm{KD} /$ KD-like illness triggered by SARS-CoV-2. This may help in a better understanding of this illness in particular and $\mathrm{KD}$ in general.

In this review, we also evaluate the safety of aspirin in influenza-triggered KD. Given the risk of development of Reye syndrome, when aspirin is administered in children with influenza, this assessment is of crucial clinical significance.

\section{Search strategy}

Two authors (AZB and AM) independently retrieved articles on influenza and KD. Both influenza $\mathrm{A}\left(\mathrm{H}_{1} \mathrm{~N}_{1}\right.$ and non- $\left.\mathrm{H}_{1} \mathrm{~N}_{1}\right)$ and influenza $\mathrm{B}$ infections were included. Besides, articles describing KD as an adverse event following influenza immunization were also included in the analysis. Literature search was performed using PubMed/Medline and Google Scholar databases. Keywords included in the search were 'Kawasaki disease' and 'influenza'; 'Kawasaki disease' and 'H1N1'; 'Kawasaki disease' and 'virus'; 'Kawasaki disease' and 'vaccine'; 'Kawasaki disease' and 'pandemic'; and 'vasculitis' and 'vaccine'. All English language articles were included. Articles in other languages with English language abstracts or titles were also included. References of the articles included were also checked to obtain additional articles. Reports describing infections or vaccinations associated with $\mathrm{KD}$ were also searched for data regarding influenza infection and vaccination.

Details of our patient and data obtained from the literature search were entered into a predesigned Excel spreadsheet (Microsoft Office 2010) to perform a combined analysis. Data regarding age, gender, clinical features (relating to $\mathrm{KD}$ ), duration of fever before presentation and intravenous immunoglobulin (IVIg) treatment, laboratory investigations, coronary echocardiography, and treatment outcome were included.

Data on $\mathrm{H}_{1} \mathrm{~N}_{1}$ and $\mathrm{KD}$, influenza (A or B or unspecified) and $\mathrm{KD}$, and influenza vaccination and $\mathrm{KD}$ were analyzed separately to derive the results. Values of parameters have been expressed as mean (range) $\left[y_{\mathrm{a}}\right]$ or percentages $[n \times$ 100], with ' $n$ ' used to denote the number of cases $(x)$ out of the cohort examined $(y)[n=x / y]$. The subscript ' $\mathrm{a}$ ' in $\left[y_{\mathrm{a}}\right]$ denotes the cohort included for analysis where $a=1$ for $\mathrm{H}_{1} \mathrm{~N}_{1}$ and KD, $a=i$ for influenza and KD, and $a=v$ for influenza vaccination and $\mathrm{KD}$.

\section{Case presentation}

In February 2019, a 9-year-old girl presented with fever for 7 days (maximum up to $104^{\circ} \mathrm{F}$ ). She developed a nonproductive cough on day 2 of illness and fast breathing on day 3 of illness. She was treated with oral antimicrobials at a local healthcare facility. However, she persisted to have fever and respiratory distress for which she was referred to our institute.

On examination, she had pallor, tachypnea (respiratory rate of 44 per minute), chest wall retractions, bilateral coarse crepitations, and hypoxia $\left(\mathrm{SpO}_{2}-88 \%\right.$ on room air). Investigations showed leukopenia (total leucocyte count of $1.8 \times 10^{9} / \mathrm{L}$ ) and thrombocytopenia (platelet count $87 \times 10^{9} /$ $\left.\mathrm{L}\left(150-400 \times 10^{9} / \mathrm{L}\right)\right)$. Chest radiograph revealed patchy consolidation predominantly involving the right middle and lower lobes (Fig. 1a). Nasopharyngeal swab showed $\mathrm{H}_{1} \mathrm{~N}_{1}$-pdm09 virus on reverse-transcription polymerase chain reaction (RTPCR) test. She required respiratory support in the form of noninvasive continuous positive airway pressure (CPAP) therapy (initial pressure: $6 \mathrm{~cm}$ of water, initial $\mathrm{FiO}_{2}: 60 \%$ ). She was treated with oral oseltamivir (60 mg twice daily for 5 days). This resulted in improvement of respiratory distress and weaning off from $\mathrm{CPAP} / \mathrm{O}_{2}$ therapy. The leukocyte count and platelet count also normalized (Fig. 1c). 

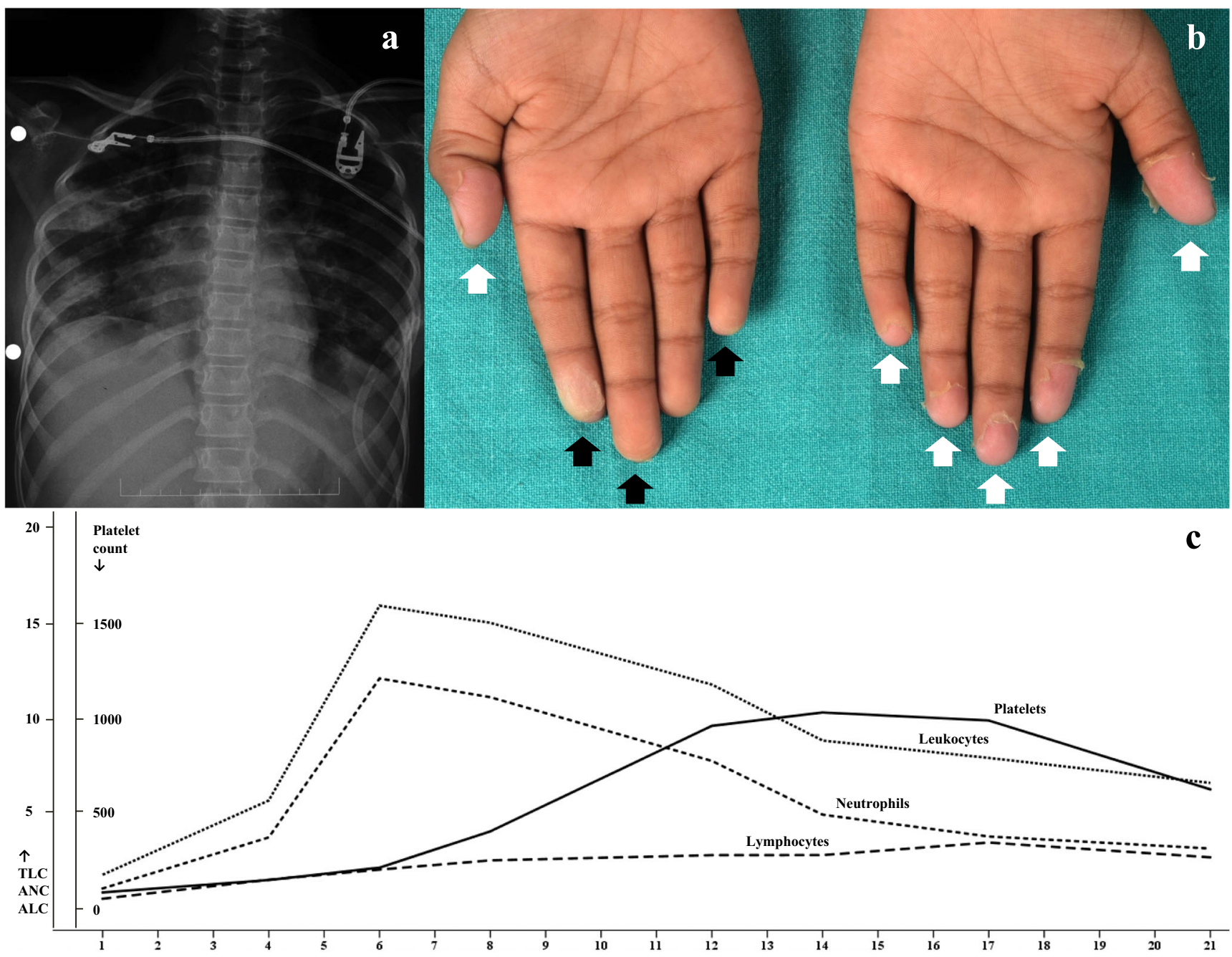

Fig. 1 Kawasaki disease triggered by $\mathrm{H}_{1} \mathrm{~N}_{1}$-pdm09 influenza infection. a Chest radiograph showing patchy areas of consolidation in upper, middle, and lower lobes of right lung with collapse of the ipsilateral middle lobe. Left paracardiac infiltrates are also noted. b Characteristic periungual peeling (white arrows) noted in both hands; premonitory coarsening of

skin of the finger pulps just beginning to peel is also noted (black arrows) [25]. c Trend of parameters on complete blood count in index child $(y$ axis: parameter value $\left(\times 10^{9} / \mathrm{L}\right), x$-axis: day of hospitalization; abbreviations: TLC: total leukocyte count, ANC: absolute neutrophil count, and ALC: absolute lymphocyte count)

However, she continued to have fever, developed neutrophilic leukocytosis, and progressive thrombocytosis (Fig. 1c). Elevated erythrocyte sedimentation rate (ESR) was $71 \mathrm{~mm}$ in the 1st hour (normal <20) and C-reactive protein $(\mathrm{CRP})$ was $22 \mathrm{mg} / \mathrm{L}$ (normal <6). She was empirically treated with intravenous antimicrobials (ceftriaxone and cloxacillin) considering a possibility of secondary bacterial infection. Fever, however, persisted. Repeat blood and sputum cultures were noncontributory; multiple sputum specimens for acid-fast bacilli staining and mycobacterial cartridge-based nucleic acid amplification test were negative; urine microscopy was normal, and urine culture was sterile. Her biochemical investigations were normal except for mild elevations in alanine and aspartate aminotransferases (110 and $55 \mathrm{U} / \mathrm{L}$, respectively [normal $<45]$ ) (Supplementary Table 1).

On day 11 of hospital stay, she developed characteristic periungual skin peeling (Fig. 1b). Incomplete KD was considered given the findings of persistent fever, periungual peeling, neutrophilic leukocytosis, thrombocytosis, and elevated inflammatory parameters (ESR, CRP) (Fig. 1c). Intravenous immunoglobulin $(2 \mathrm{~g} / \mathrm{kg})$ was administered and this resulted in resolution of fever. Aspirin ( $3 \mathrm{mg} / \mathrm{kg} /$ day) was given during the acute stage and continued for 6 weeks. 2D transthoracic echocardiography showed normal coronary arteries and myocardial function throughout her illness. Nterminal pro-B-type natriuretic peptide (NT-proBNP) also remained normal $(6.81 ; 19.53 \mathrm{pg} / \mathrm{mL}$ [normal < 125]). She is currently well at 1.5 years of follow-up.

\section{Results}

We reviewed 16 articles describing influenza infection or vaccination in association with KD. Of these, six were 
retrospective studies describing one or more cases and the rest (10) were individual case reports describing a single patient. Complete clinical and laboratory details of patients with influenza infection-associated $\mathrm{KD}$ were available in all case reports. However, only one among the retrospective studies had complete details.

\section{$H_{1} N_{1}$ influenza and KD}

To date, five case reports (including ours) specifically describe $\mathrm{H}_{1} \mathrm{~N}_{1}-\mathrm{KD}$ (total patients $\left[y_{1}\right]=5$ ) (Table 1). Mean age at presentation was 41 months (5-108) $[y=5]$ and $80 \%[n=$ 4/5] were males. Excluding our case (who presented at 109 months), mean age at presentation was 24 months. Mean duration of fever before presentation was 7 days (3-9) $\left[y_{1}=5\right]$ and IVIg was administered at a mean of 13 days of fever (918) $\left[y_{1}=5\right]$. Incomplete $\mathrm{KD}$ was diagnosed in $60 \%[n=3 / 5]$. All five children had a good response to IVIg. Dilatation of the left main coronary artery developed in $40 \%[n=2 / 5]$ and it normalized on follow-up. Aspirin in doses varying from 3 to $50 \mathrm{mg} / \mathrm{kg} /$ day was used in all five patients; however, Reye syndrome was not documented in any of these cases.

\section{Non- $\mathrm{H}_{1} \mathrm{~N}_{1}$ influenza and KD}

Influenza infection and concomitant $\mathrm{KD}$ have been reported in about 38 patients to date (4 case reports and 5 retrospective studies) - 21 with influenza A and 11 with influenza B, and in the remaining 6 , data on type of influenza virus were unavailable (Table 2). Mean age at diagnosis was 24 months (2-48) $\left[y_{\mathrm{i}}=19\right]$ with all cases occurring before 48 months of age. Boys constituted $63 \%$ of this cohort $(n=12 / 19)$. Incomplete $\mathrm{KD}$ was diagnosed in $32 \%(n=6 / 19)$. Coronary artery dilatations were noted in 50\% ( $n=9 / 18)$. IVIg resistance was noted in $18 \%(n=3 / 17)$; this was managed with second dose IVIg in one patient [13]. Treatment details of the other two patients were not available [17]. In the influenza infection and KD cohort, two patients did not receive IVIg as the fever resolved spontaneously within 1 week. Aspirin was used in at least $53 \%$ of patients $(n=20 / 38)$ with dosage details available for five patients. In one patient, aspirin doses of up to 80-100 $\mathrm{mg} / \mathrm{kg} /$ day were used [15], whereas, the other four received only antiplatelet doses [16]. Reye syndrome was not reported in any of the influenza patients with KD.

\section{Influenza vaccination and KD}

Influenza vaccination has been reported to trigger $\mathrm{KD}$ in 2 case reports ( 1 case each), in addition to a large multicentric retrospective study reporting approximately 20 cases [24]. The two cases (reported in the two case reports) developed $\mathrm{KD}$ after 1 and 8 days of influenza vaccination, respectively; however, data regarding temporal correlation of $\mathrm{KD}$ with vaccination or the clinical/laboratory details of individual patients were not available in the large multicentric study. Incomplete $\mathrm{KD}$ or CAAs were not reported in these patients. However, one of the patients had myocarditis (low ejection fraction and elevated NT-proBNP) with IVIg resistance that was successfully managed with a second dose of IVIg. Both patients had neutrophilia and elevated CRP $(\sim 150 \mathrm{mg} / \mathrm{L})$ and received aspirin in doses of up to 30 and $50 \mathrm{mg} / \mathrm{kg} / \mathrm{day}$, respectively (Table 3 ).

\section{Discussion}

Kawasaki disease is a systemic inflammatory disease of unknown etiology; however, an infectious trigger has been incriminated in etiopathogenesis of this condition. Positive respiratory virus PCR for influenza, parainfluenza, adenovirus, rhinovirus, enterovirus, human bocavirus, and human metapneumovirus has been reported in children with $\mathrm{KD}$ $[19,26]$. Autopsy studies have also implicated a specific RNA respiratory virus in pathogenesis of KD. Role of respiratory viruses in triggering $\mathrm{KD}$ has generated much interest recently due to $\mathrm{KD} / \mathrm{KD}$-like as being reported in association with the current SARS-CoV-2 pandemic.

We report a child with an uncommon association of $\mathrm{H}_{1} \mathrm{~N}_{1}$ influenza being complicated with $\mathrm{KD}$. The index child was diagnosed as $\mathrm{H}_{1} \mathrm{~N}_{1}$-influenza at admission (day 1 of hospitalization) and, subsequently, KD was diagnosed on day 11 of hospital stay. The diagnostic procedures (summarized in Supplementary Table 1) performed in index child, although not exhaustive, could not identify any other potential trigger. Based on the close temporal proximity and absence of a suitable alternative explanation, a final diagnosis of influenza $\left(\mathrm{H}_{1} \mathrm{~N}_{1}\right)$-triggered $\mathrm{KD}$ was proffered [27].

We also performed a detailed literature review of available reports of KD triggered by influenza infection or vaccination. From an epidemiological perspective, influenza infection in context of KD has been reported from North America, Europe, and East Asia - our report is the first from South Asia. Reports from Japan on influenza infection or vaccination triggering $\mathrm{KD}$ are sparse (two case reports describing one case each) $[14,22]$. This is in stark contrast to the fact that Japan has the highest incidence of KD in the world [28]. In fact, epidemiological studies from Japan have described a suppressive effect of influenza outbreaks on incidence of KD [29]. Genetic influences may seem to be the most logical explanation; however, it is still a work in progress.

Mean age of onset for influenza-KD is 2 years and this is similar to $\mathrm{KD}$ as a whole. Index child with $\mathrm{H}_{1} \mathrm{~N}_{1}-\mathrm{KD}$ was 9 years old at presentation and is among the very few influenza$\mathrm{KD}$ cases that have been reported in children above 5. As many as $50 \%$ patients with influenza-KD develop CAAs. This could be due to the fact that influenza-KD is often 


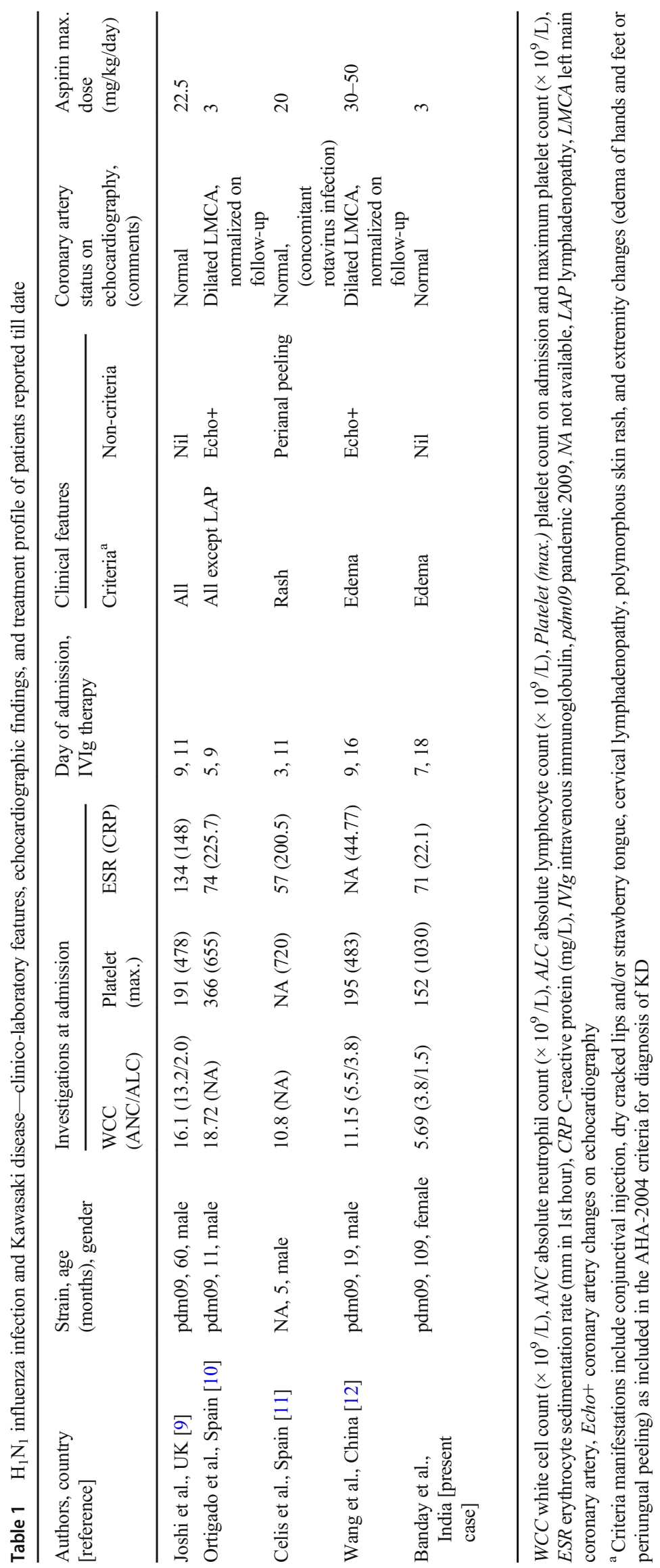




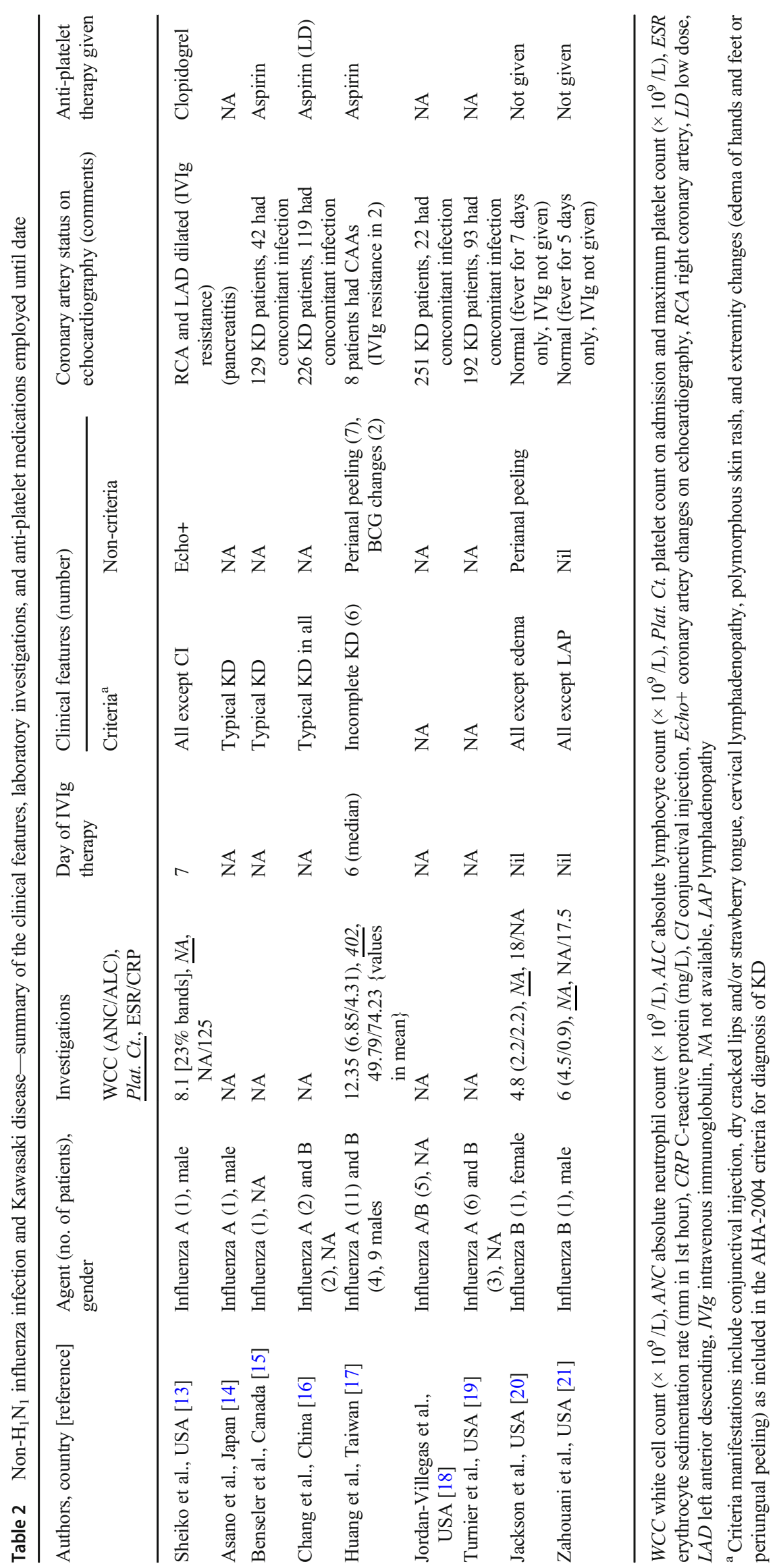


Table 3 Clinical profile of patients with influenza immunization and Kawasaki disease

\begin{tabular}{|c|c|c|c|c|c|c|c|c|c|}
\hline \multirow{2}{*}{$\begin{array}{l}\text { Authors, } \\
\text { country } \\
\text { [reference] }\end{array}$} & \multirow{2}{*}{$\begin{array}{l}\text { Disease } \\
\text { onset after } \\
\text { vaccination }\end{array}$} & \multicolumn{3}{|c|}{ Investigations } & \multirow{2}{*}{$\begin{array}{l}\text { Day of } \\
\text { IVIg } \\
\text { therapy }\end{array}$} & \multicolumn{2}{|c|}{ Clinical features } & \multirow{2}{*}{$\begin{array}{l}\text { Coronary artery } \\
\text { status on } \\
\text { echocardiography } \\
\text { (comments, no. of cases) }\end{array}$} & \multirow{2}{*}{$\begin{array}{l}\text { Aspirin } \\
\text { max. } \\
\text { dose } \\
(\mathrm{mg} / \mathrm{kg} \\
\text { day) }\end{array}$} \\
\hline & & $\begin{array}{l}\text { WCC } \\
\text { (ANC) }\end{array}$ & $\begin{array}{l}\text { Plat. } \\
(\max )\end{array}$ & $\begin{array}{l}\text { ESR } \\
(\mathrm{CRP})\end{array}$ & & Criteria $^{a}$ & Non-criteria & & \\
\hline $\begin{array}{l}\text { Shimada et al., } \\
\text { Japan [22] }\end{array}$ & 8 days & 24.5 (NA) & NA & NA (145) & $\sim 5$ & All & Nil & Normal (-, 1 (female)) & 30 \\
\hline $\begin{array}{l}\text { Jeong et al., } \\
\text { South Korea } \\
{[23]}\end{array}$ & 1 day & $12.1(7.9)$ & $344(625)$ & $70(151)$ & 6 & $\begin{array}{l}\text { All except } \\
\text { LAP }\end{array}$ & $\begin{array}{l}\text { BCG site } \\
\quad \text { changes, } \\
\text { decreased EF }\end{array}$ & $\begin{array}{l}\text { Normal (IVIg resistance, } \\
\quad 1 \text { (male)) }\end{array}$ & 50 \\
\hline $\begin{array}{l}\text { Felicetti et al., } \\
\text { multicentric } \\
\text { [24] }\end{array}$ & NA & NA & & & NA & NA & NA & $\begin{array}{l}\text { NA (8\% vaccine-related } \\
\text { KD due to influenza, } \\
\sim 20 \text { ) }\end{array}$ & NA \\
\hline
\end{tabular}

WCC white cell count $\left(\times 10^{9} / \mathrm{L}\right), A N C$ absolute neutrophil count $\left(\times 10^{9} / \mathrm{L}\right)$, Plat. $(\max )$ platelet count on admission and maximum platelet count $\left(\times 10^{9} /\right.$ $\mathrm{L}), E S R$ erythrocyte sedimentation rate ( $\mathrm{mm}$ in 1 st hour), CRP C-reactive protein $(\mathrm{mg} / \mathrm{L}), L A P$ lymphadenopathy, EF ejection fraction (cardiac), IVIg intravenous immunoglobulin, $N A$ not available

${ }^{a}$ Criteria manifestations include conjunctival injection, dry cracked lips and/or strawberry tongue, cervical lymphadenopathy, polymorphous skin rash, and extremity changes (edema of hands and feet or periungual peeling) as included in the AHA-2004 criteria for diagnosis of KD

incomplete. As a result, delays in diagnosis and institution of therapy are understandable, as was the case in our patient as well. Nonetheless, giant aneurysms have not been reported in influenza-KD, and treatment with IVIg has been reported to result in resolution of coronary artery dilatations seen in such cases. Biologics (infliximab, anakinra, and etanercept) and immunosuppressive medications (steroids and ciclosporin) have not been used in patients with influenza-KD.

The American Heart Association 2017 Guidelines have suggested that alternatives to aspirin should be considered in children with influenza and KD. Children on prolonged highdose aspirin therapy are at risk of Reye syndrome [3]. Majority of patients with influenza-KD reported to date have received aspirin (including doses as high as $80-100 \mathrm{mg} / \mathrm{kg} /$ day for a few days) without Reye syndrome being reported. In our case, aspirin in antiplatelet doses was administered. Based on these findings, at least low-moderate doses of aspirin appear to be safe in children with influenza-KD, especially when used for a short duration. However, more data are needed to formulate evidence-based recommendations regarding administration of aspirin in influenza-KD.
A comprehensive summary of the available literature on the intriguing association of influenza with $\mathrm{KD}$ including a description on the safety of aspirin in influenza-triggered $\mathrm{KD}$ are the important strengths of our case-based review. However, non-systematic literature search limited to PubMed and Google Scholar databases is an important limitation of our study.

\section{Influenza-KD—a sequitur}

Besides secondary bacterial infection, KD should also be considered in children with influenza who have persistent fever despite antiviral therapy. Laboratory findings of progressive neutrophilic leukocytosis or thrombocytosis or marked elevations of CRP may be pointers towards KD. Assessment of coronary artery dimensions by $2 \mathrm{D}$ echocardiography is crucial, as about half of the patients with influenza-KD may develop CAAs. Anti-platelet doses (3-5 mg/ $\mathrm{kg} /$ day) of aspirin, used for periods up to 6 weeks, appear to be safe in children with influenza-KD. Even moderate $(30-50 \mathrm{mg} / \mathrm{kg} /$ day) to
Table 4 Important contrasting features of KD/KD-like illness seen in association with SARS$\mathrm{CoV}-2$ as compared with influenza infection-triggered $\mathrm{KD}$

\begin{tabular}{llll}
\hline Characteristic of KD/KD-like illness & $\mathrm{H}_{1} \mathrm{~N}_{1}$ infection & Influenza infection & SARS-CoV-2 $^{\mathrm{a}}$ \\
\hline Median age at diagnosis (years) & 1.6 & 2 & $8-10$ \\
Median illness duration prior to diagnosis (days) & 11 & 6 & $21-25$ \\
Male/female ratio & $4: 1$ & $\sim 2: 1$ & $\sim 3: 2$ \\
Coronary artery abnormalities (percentage (\%)) & 40 & 50 & $6-9$ \\
Myocarditis/decreased ejection fraction (\%) & 0 & 0 & $38-66$ \\
Treatment with IVIg (\%) & 100 & 95 & $54-77$ \\
Mortality (\%) & 0 & 0 & $2-3$ \\
\hline
\end{tabular}

${ }^{a}$ Data calculated from references [6-8] 
high $(80-100 \mathrm{mg} / \mathrm{kg} /$ day) doses of aspirin may be safe in children with influenza-KD when used for few days only; however, data in this regard are still sparse.

\section{New insights}

Similar to the relative paucity of reports regarding association of KD with influenza from Japan, reports of SARS-CoV-2 and KD-like illness are also scarce from Japan [30]. While influenza-KD is primarily seen in children $<5, \mathrm{KD}$-like illness in context of SARS-CoV-2 is a disease of older children (median age $\sim 9-10$ years) $[7,8]$. On the other hand, both illnesses have male predilection $[6,8]$. While influenza-KD has been reported to occur within 3 weeks of antecedent influenza infection or vaccination, $\mathrm{KD}$-like clinical features in association with SARS-CoV-2 often occur after 3 weeks of initial illness $[6,8]$.

Myocarditis, elevated NTpro-BNP, and decreased ejection fraction have been reported in an 18-month-old girl with $\mathrm{KD}$ following influenza vaccination; however, myocardial involvement has not been reported in any child with influenza infection and KD. Influenza and SARS-CoV-2 appear to have a different pattern of cardiac involvement when these viruses result in $\mathrm{KD} / \mathrm{KD}$-like illness - predominantly myocardial involvement in SARS-CoV-2 and CAAs in influenza (Table 4) [6-8].

The hyper-inflammatory response associated with SARSCoV-2 may be a manifestation of dysregulated immune response. Novelty of this coronavirus or lack of vaccination for related coronaviruses may be contributing factors. It would be interesting to see how the KD-like illness associated with SARS-CoV-2 evolves when vaccines for the novel coronavirus are used in children.

\section{Conclusion}

KD triggered by influenza infection seems to be distinct from $\mathrm{KD} / \mathrm{KD}$-like illness associated with SARS-CoV-2. While influenza-triggered $\mathrm{KD}$ peaks at 2 years of age and occurs within 3 weeks of the onset of influenza, KD/KD-like illness post-SARS-CoV-2 peaks at $8-10$ years, and often occurs more than 3 weeks of the antecedent illness. Influenzatriggered $\mathrm{KD}$ commonly affects coronaries whereas $\mathrm{KD} / \mathrm{KD}$ like illness post-SARS-CoV-2 predominantly affects the myocardium.

Supplementary Information The online version contains supplementary material available at https://doi.org/10.1007/s10067-020-05534-1.

Authors' contributions AZB: patient management and follow-up, inception of idea, writing of initial draft of manuscript, editing and revision of manuscript at all stages of its production, review of literature, and final approval.

AR: patient management and follow-up, inception of idea, writing of initial draft of the manuscript, contributed to editing of manuscript, review of literature, and final approval.

PV: patient management and follow-up, editing of manuscript, critical revision of the manuscript at all stages of production, and final approval.

MPS/KG: performed virological investigations of index child, contributed to editing of manuscript, and final approval.

SS: patient management and follow-up, contributed to editing of manuscript, revision of the manuscript, and its final approval.

Data availability Relevant data included in Tables 1, 2, and 3.

\section{Compliance with ethical standards}

Disclosures None.

Ethical approval and informed consent As this manuscript pertains only to a case-based review, specific ethics approval is not mandated.

Consent Informed consent has been obtained from parents of the case reported here.

\section{References}

1. Wood LE, Tulloh RM (2009) Kawasaki disease in children. Heart 95(10):787-792. https://doi.org/10.1136/hrt.2008.143669

2. Kawasaki T (1967) Acute febrile mucocutaneous syndrome with lymphoid involvement with specific desquamation of the fingers and toes in children. Arerugi 16(3):178-222 [Article in Japanese]

3. McCrindle BW, Rowley AH, Newburger JW, Burns JC, Bolger AF, Gewitz M et al (2017) Diagnosis, treatment, and long-term management of Kawasaki disease: a scientific statement for health professionals from the American Heart Association. Circulation 135(17):e927-e999. https://doi.org/10.1161/CIR. 0000000000000484

4. Liang YC, Chang $\mathrm{CH}$, Lin MT, Kao FY, Huang SK, Wu MH (2020) Shock and unresponsiveness to repeated courses of intravenous immunoglobulin in Kawasaki disease: a nationwide database study. Pediatr Res 87(5):961-966. https://doi.org/10.1038/s41390019-0668-1

5. Nakamura A, Ikeda K, Hamaoka K (2019) Aetiological significance of infectious stimuli in Kawasaki disease. Front Pediatr 7: 244. https://doi.org/10.3389/fped.2019.00244

6. Feldstein LR, Rose EB, Horwitz SM, Collins JP, Newhams MM, Son MBF, Newburger JW, Kleinman LC, Heidemann SM, Martin AA, Singh AR, Li S, Tarquinio KM, Jaggi P, Oster ME, Zackai SP, Gillen J, Ratner AJ, Walsh RF, Fitzgerald JC, Keenaghan MA, Alharash H, Doymaz S, Clouser KN, Giuliano JS Jr, Gupta A, Parker RM, Maddux AB, Havalad V, Ramsingh S, Bukulmez H, Bradford TT, Smith LS, Tenforde MW, Carroll CL, Riggs BJ, Gertz SJ, Daube A, Lansell A, Coronado Munoz A, Hobbs CV, Marohn KL, Halasa NB, Patel MM, Randolph AG, Overcoming COVID-19 Investigators, CDC COVID-19 Response Team (2020) Multisystem inflammatory syndrome in U.S. children and adolescents. N Engl J Med 383(4):334-346. https://doi.org/10.1056/ NEJMoa2021680

7. Dufort EM, Koumans EH, Chow EJ, Rosenthal EM, Muse A, Rowlands J, Barranco MA, Maxted AM, Rosenberg ES, Easton D, Udo T, Kumar J, Pulver W, Smith L, Hutton B, Blog D, Zucker H, New York State and Centers for Disease Control and 
Prevention Multisystem Inflammatory Syndrome in Children Investigation Team (2020) Multisystem inflammatory syndrome in children in New York State. N Engl J Med 383(4):347-358. https://doi.org/10.1056/NEJMoa2021756

8. Kaushik S, Aydin SI, Derespina KR, Bansal PB, Kowalsky S, Trachtman R, Gillen JK, Perez MM, Soshnick SH, Conway EE Jr, Bercow A, Seiden HS, Pass RH, Ushay HM, Ofori-Amanfo G, Medar SS (2020) Multisystem inflammatory syndrome in children associated with severe acute respiratory syndrome coronavirus 2 infection: a multi-institutional study from New York City. J Pediatr 224:24-29. https://doi.org/10.1016/j.jpeds.2020.06.045

9. Joshi AV, Jones KD, Buckley AM, Coren ME, Kampmann B (2011) Kawasaki disease coincident with influenza A H1N1/09 infection. Pediatr Int 53(1):e1-e2. https://doi.org/10.1111/j.1442200X.2010.03280.x

10. Ortigado A, Olloqui A, Mazario GJ, Eliana R, Cid E, Bustos JJ (2010) Kawasaki disease and H1N1 influenza a virus: a case report. Acta Paediatr 99(Suppl. 462):89

11. Carbonero-Celis MJ, De Cueto M, Carbonero-Santaella A, HaroGómez M (2013) Enfermedad de Kawasaki incompleta concomitante con coinfección por el virus influenza A H1N1 y rotavirus [Incomplete Kawasaki disease concomitant with influenza A H1N1 virus and rotavirus coinfection]. Enferm Infecc Microbiol Clin 31(2):125-126. [Article in Spanish]. https://doi.org/10.1016/j. eimc.2012.07.010

12. Wang J, Sun F, Deng HL, Liu RQ (2019) Influenza A (H1N1) pdm09 virus infection in a patient with incomplete Kawasaki disease: a case report. Medicine (Baltimore) 98(15):e15009. https:// doi.org/10.1097/MD.0000000000015009

13. Sheiko M, Soma V, Moss N, Frenkel L (2010) Case of concurrent influenza A and Kawasaki disease. J Pediatr Infect Dis 5(2):211213. https://doi.org/10.3233/JPI-2010-0241

14. Asano T, Sasaki N, Yashiro K, Hatori T, Kuwabara K, Hamada H, Imai T, Fujino O (2005) Acute pancreatitis with Kawasaki disease: analysis of cases with elevated serum amylase levels. Eur J Pediatr 164(3):180-181. https://doi.org/10.1007/s00431-004-1589-4

15. Benseler SM, McCrindle BW, Silverman ED, Tyrrell PN, Wong J, Yeung RS (2005) Infections and Kawasaki disease: implications for coronary artery outcome. Pediatrics 116(6):e760-e766. https://doi. org/10.1542/peds.2005-0559

16. Chang LY, Lu CY, Shao PL, Lee PI, Lin MT, Fan TY, Cheng AL, Lee WL, Hu JJ, Yeh SJ, Chang CC, Chiang BL, Wu MH, Huang LM (2014) Viral infections associated with Kawasaki disease. J Formos Med Assoc 113(3):148-154. https://doi.org/10.1016/j. jfma.2013.12.008

17. Huang X, Huang P, Zhang L, Xie X, Xia S, Gong F, Yuan J, Jin L (2015) Influenza infection and Kawasaki disease. Rev Soc Bras Med Trop 48(3):243-248. https://doi.org/10.1590/0037-86820091-2015

18. Jordan-Villegas A, Chang ML, Ramilo O, Mejías A (2010) Concomitant respiratory viral infections in children with
Kawasaki disease. Pediatr Infect Dis J 29(8):770-772. https://oi. org/10.1097/INF.0b013e3181dba70b

19. Turnier JL, Anderson MS, Heizer HR, Jone PN, Glodé MP, Dominguez SR (2015) Concurrent respiratory viruses and Kawasaki disease. Pediatrics 136(3):e609-e614. https://doi.org/ 10.1542/peds.2015-0950

20. Jackson MA, Burry VF (1993) Influenza mimicking Kawasaki disease. Pediatr Infect Dis J 12(9):787-788. https://doi.org/10.1097/ 00006454-199309000-00023

21. Zahouani T, Lopez JV, Sitnitskaya Y (2018) Influenza with rash or influenza with Kawasaki disease? Med Microbiol Rep 2:1 104172/ MMR.100017

22. Shimada S, Watanabe T, Sato S (2015) A patient with Kawasaki disease following influenza vaccinations. Pediatr Infect Dis J 34(8): 913. https://doi.org/10.1097/INF.0000000000000713

23. Jeong SW, Kim DH, Han MY, Cha SH, Yoon KL (2018) An infant presenting with Kawasaki disease following immunization for influenza: a case report. Biomed Rep 8(3):301-303. https://doi.org/ $10.3892 / \mathrm{br} .2018 .1043$

24. Felicetti P, Trotta F, Bonetto C, Santuccio C, Pernus YB, Burgner D et al (2016) Spontaneous reports of vasculitis as an adverse event following immunization: a descriptive analysis across three international databases. Vaccine 34(51):6634-6640. https://doi.org/10. 1016/j.vaccine.2015.09.027

25. Jindal AK, Singh S (2017) Dryness at fingertips: is it a premonitory sign of skin peeling in Kawasaki disease? J Clin Rheumatol 23(5): 286. https://doi.org/10.1097/RHU.0000000000000519

26. Kim JH, Yu JJ, Lee J, Kim MN, Ko HK, Choi HS, Kim YH, Ko JK (2012) Detection rate and clinical impact of respiratory viruses in children with Kawasaki disease. Korean J Pediatr 55(12):470-473. https://doi.org/10.3345/kjp.2012.55.12.470

27. Higuchi Y, Ochi M, Shimizu J, Furujo M (2020) A 9-year-old girl with Kawasaki disease and pulmonary nodules. Clin Rheumatol 39(10):3139-3140. https://doi.org/10.1007/s10067-020-05222-0

28. Ae R, Makino N, Kosami K, Kuwabara M, Matsubara Y, Nakamura Y (2020) Epidemiology, treatments, and cardiac complications in patients with Kawasaki Disease: the Nationwide Survey in Japan, 2017-2018. J Pediatr 225:23-29.e2. https://doi. org/10.1016/j.jpeds.2020.05.034

29. Awaya A (2016) Suppressive influence of seasonal influenza epidemic on Kawasaki disease onset. Nihon Rinsho Meneki Gakkai Kaishi 39(6):528-537. https://doi.org/10.2177/jsci.39.528

30. Iio K, Uda K, Hataya H, Yasui F, Honda T, Sanada T, Yamaji K, Kohara M, Itokawa M, Miura M (2020) Kawasaki disease or Kawasaki-like disease: influence of SARS-CoV-2 infections in Japan [published online ahead of print, 2020 Aug 16]. Acta Paediatr. https://doi.org/10.1111/apa.15535

Publisher's note Springer Nature remains neutral with regard to jurisdictional claims in published maps and institutional affiliations. 